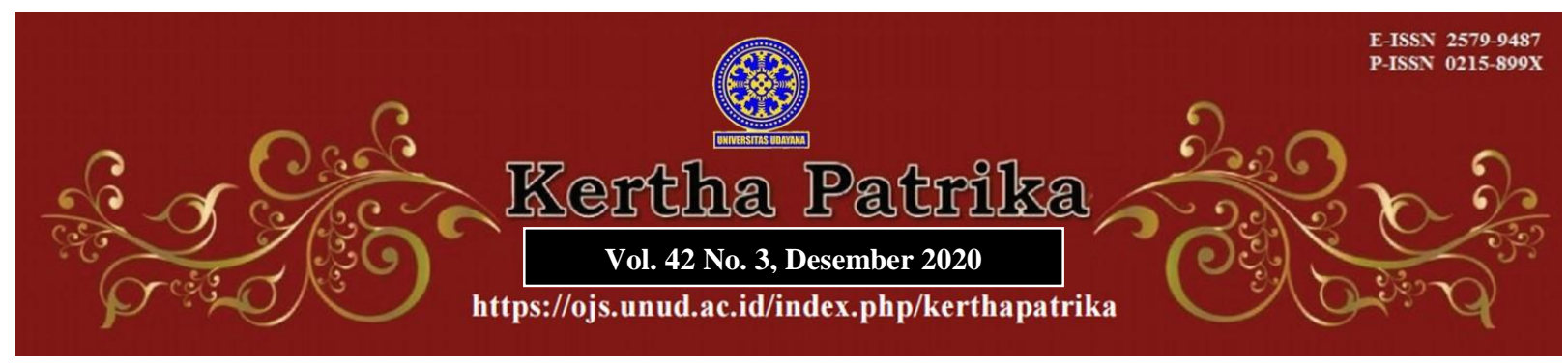

\title{
Regional Government Authority in Determining Policies on the Master Plan of Tourism Development
}

\author{
Ni Luh Gede Astariyani ${ }^{1}$, Ni Putu Wiwin Setyari², Bagus Hermanto ${ }^{3}$
}

\author{
${ }^{1}$ Faculty of Law Udayana University, E-mail: luh_astariyani@unud.ac.id \\ ${ }^{2}$ Faculty of Economy and Business Udayana University, E-mail: wiwin.setyari@unud.ac.id \\ ${ }^{3}$ Faculty of Law Udayana University, E-mail: bagushermanto9840@gmail.com
}

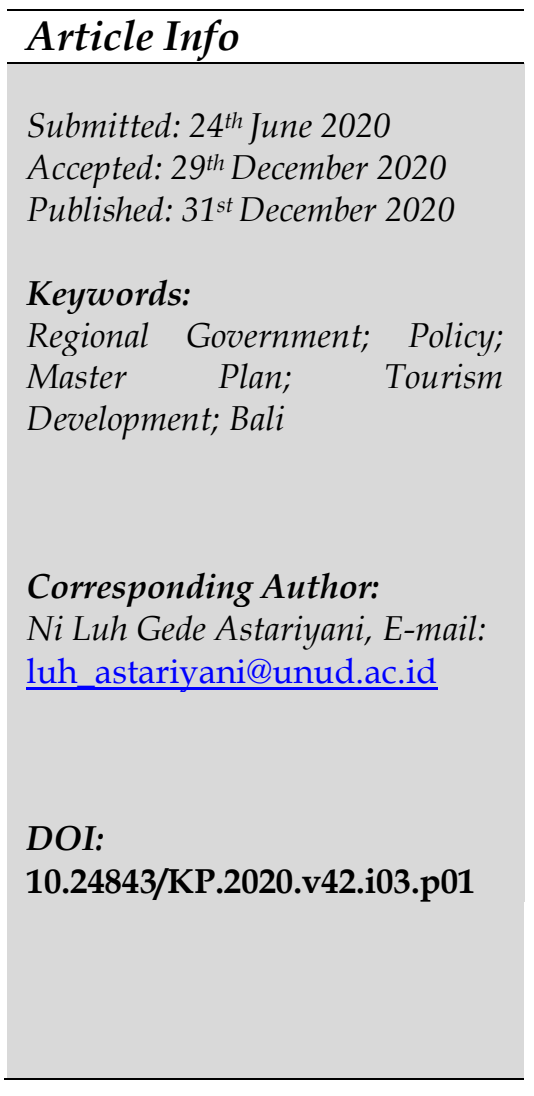

\begin{abstract}
This study intends to examine the authority of local governments to regulate regional policies on tourism development master plan. This paper examines the legal issues related to the basis of the authority from philosophical, sociological, and juridical aspects of the formation of policies regarding tourism development plans. This paper focuses on the target, scope, content, and direction of Regional Regulations concerning tourism development plans to establish legislation and prioritizing aspects of the tourism industry, marketing destinations, and culture of Bali Tourism. It is a legal research that uses statutory, philosophical, theoretical, and conceptual approaches. The research resulted that the basis of authority for delegation of formation arrangements is regulated in the Law concerning Tourism, Government Regulation, and Regional Government Law related to the Master Plan of National Tourism Development. The basis of regional government authority in setting these policies is the enactment of local regulations of Bali Province, Badung Regency, Jembrana Regency, and Denpasar City concerning regional tourism development master plan. However, the mandatory obligations for regional government in determining tourism development master plan have not immediately been taken effect by the other regency governments in Bali Province.
\end{abstract}

\section{Introduction}

There are a lot of well-known tourist destinations in the world inter alia Bali as one of well-known tourist destination that visited both from domestic or foreign tourists (in Balinese phrase is called as kaloktah kantos ke dura negara), for example Tanah Lot, Trunyan, Batur Geopark, Kuta, Seminyak, Beratan Lake. ${ }^{1}$ The number of tourists visiting Bali from year to year is relatively experiencing an increase especially for foreign

\footnotetext{
1 Astariyani, N.L.G. \& Nurmawati, M. (2017). Drafting the Substance Materials of the Regional Regulation of Badung Regency on Public Service. Udayana Journal of Social Science and Humanities 1 (1), 42-45, DOI: https/ / doi.org/10.24843/UJoSSH.2017.v01.i01.p08, p. 43.
} 
tourists, based on Statistic Centre Bali Province (Badan Statistik Provinsi Bali), ${ }^{2}$ in 2011 until 2019, show significant growth number started from 2011 reach 2.826 .709 tourists, in 2012 reach 2.949.332 tourists, in 2013 reach 3.278 .598 tourists, in 2014 reach 3.766 .638 tourists, in 2015 reach 4.001 .835 tourists, in 2016 reach 4.927 .937 tourists, in 2017 reach 5.697.739 tourists, in 2018 reach 6.070.473 tourists, and in 2019 reach 6.275.210 tourists. From domestic tourists, it also showing increase number from 2011 until 2018, in 2011 reach 5.675.121 tourists, in 2012 reach 6.063 .558 tourists, in 2013 reach 6.976 .536 tourists, in 2014 reach 6.394 .307 tourists, in 2015 reach 7.147.100 tourists, in 2016 reach 8.643.680 tourists, in 2017 reach 8.735.633 tourists, and in 2018 reach 9.757 .991 tourists. ${ }^{3}$ It means that Bali was recognized as one of the most prestigious tourist destinations in the world and also Indonesia. This situation led to the urgency of arranged tourism development. Tourism development requires the development of quality regional tourism development, which is community-based and sustainable. In very rapid development, there is also needs a policy tool that is the basis for strengthening the regulation ${ }^{4}$ of tourism development, especially for regional tourism to be well maintained.

The policy on the tourism master plan in the area provides guidelines related to a strategic tourism area development within the one or more administrative regions in areas that potentially for tourist attraction, high accessibility, availability of public facilities and tourism facilities as well as social and cultural activities of the community which support each other in the realization of tourism.

The importance of formulating the authority of Regional Governments in setting policies on the Master Plan for Tourism Development aims to implement the role of the province and local government, ${ }^{5}$ in this context is to provide planning related to tourism development. ${ }^{6}$ The development of regional tourism includes the development of regional tourism destinations, regional tourism marketing development, regional tourism industries development, and the development of regional tourism institutions. ${ }^{7}$ At the provincial level, regional tourism development is regulated by Bali Provincial Regulation Number 10 Year 2015. At the regency/city levels, there are Badung Regional Regulation Number 17 the Year 2017, Jembrana Regional Regulation Number 1 the Year 2018, and Denpasar Regional Regulation Number 3 the Year 2019. Those regulations

2 Arranged Team of Statistic Centre of Bali Province Publications, 2020, Statistik Wisatawan Mancanegara ke Bali 2019 (Foreign Tourist Statistics of Bali Province 2019), First Edition, Badan Pusat Statistik Provinsi Bali, Denpasar, pp. 13-14.

3 Arranged Team of Statistic Centre of Bali Province Publications, 2020, Provinsi Bali dalam Angka 2020 (Bali Provinces in Figure 2020), First Edition, Badan Pusat Statistik Provinsi Bali, Denpasar, pp. 355-361, 366.

${ }^{4}$ Febriansyah, F.I. (2016). Konsep Pembentukan Peraturan Perundang-undangan di Indonesia. Perspektif: Kajian Masalah Hukum dan Pembangunan, XXI(3), 220-229, DOI: http://dx.doi.org/10.30742/perspektif.v21i3.586, pp. 222-223.

5 Suharjono, M. (2014). Pembentukan Peraturan Daerah yang Responsif dalam Mendukung Otonomi Daerah. DIH Jurnal Ilmu Hukum, 10(19), 21-37, DOI: https://doi.org/10.30996/dih.v10.i19.281, p. 25.

${ }^{6}$ Astariyani, N.L.G., Sudiarta, I.K. \& Dewi, C.I.D.W.P. (2019). Legal Hermeneutics in the Preparation of a Case in the Province of Bali. Udayana Journal of Social Science and Humanities 3(1), 33-39, DOI: https//doi.org/10.24843/UJoSSH.2019.v03.i01.p06, p. 36.

7 Sandang, Y. (2019). Pengarusutamaan Prinsip-Prinsip Bisnis dan Hak Asasi Manusia Bagi Sektor Pariwisata di Indonesia. Jurnal HAM 10(1), 1-17, DOI: http://dx.doi.org/10.30641.ham.2019.10.1-17, pp. 11-12. 
cover the fundamental and plan of tourism development in the region. It can be revealed that 6 other regencies in Bali do not enact specific regional regulation concerning tourism development. The tourism development aims to realize the quality and sustainable cultural tourism 8 and to increase tourism competitiveness based on Tri Hita Karana value $^{9}$ that can encourage regional development and people's welfare. ${ }^{10}$

Yusuf Adam Hilman focuses on the matter of the village level as a measurement for tourism policy institutions. His research is conducting ecotourism and its huge-potential that can be utilized by policymakers for tourism development. Tourism village-based tourism policy development models become designs that need to be made in-depth analysis with more orderly and dynamic mechanisms or institutions. The research does not specifically describe the hierarchical flow of tourism policy institutions that can then be implemented at the village level, and is limited with how to develop ecotourism policies in tourist villages. ${ }^{11}$ So, this paper can improve the hierarchical flow of tourism policy institutions, especially at higher levels.

Kadek Julia Mahadewi focusing on the issue of spatial planning in Bali Province, at a glance also recognize that the spatial planning problem as a result of tourism policies. Tourism policies are still unaligned with the spatial planning problem for the sustainable development of tourism in Bali. ${ }^{12}$ So, this paper can confirm the delegation of central government authority to local governments to compile a tourism development master plan that can be the key to the chain due to the implementation of tourism activities.

I Wayan Suardana stated that sustainable tourism policies in Bali, both with national and regional arrangements, reflect sustainable tourism development as a series of measured

8 Salain, M.S.P.D. (2017). Perlindungan Hukum terhadap Kebudayaan Bali sebagai Sumber Daya Ekonomi Pariwisata. Kertha Patrika 39(1), 1-15, DOI: https://doi.org/10.24843/KP.2017.v39.i01.p01, p. 8.

9 Herpin Hadat revealed that based on philosophy of science, ontologically, Tri Hita Karana determines as life guidance from harmonious relationship between each person, person with environment and person with God, being the fundamental and final principle to solving life problem for Balinese society with legal norm under regulative function, complementary function, corrective function, and punishment function, for instance Article 2 of Bali Provincial Regulation Number 2 Year 2012 recognizing Tri Hita Karana in Balinese culture tourism regulation. Epistemologically, Tri Hita Karana with Hinduism values brought explanation concerning harmonious and balance life attitude, and axiological, Tri Hita Karana understood as happiness values within each person, person with environment and person with God relationship, and adopted into legislation to remedies the morality of society. See further on: Hadat, H. (2020). Eksistensi Tri Hita Karana dalam Pembentukan Peraturan Hukum di Bali (Perspektif Filsafat Ilmu). Jurnal Magister Hukum Udayana 9(1), 132-141, DOI: https://doi.org/10.24843/JMHU.2020.v09.i01.p09, pp. 137-139.

10 Dharmawan, N.K.S., Sarjana, I M. \& Samshitawrati, P.A. (2017). Perusahaan dan Konservasi Keanekaragaman Hayati Laut: The Right to Tourism vs Sustainable Tourism, Masalah-masalah Hukum, 46(2), 125-135. DOI: 10.14710/mmh.46.2.2017.125-135, p. 128.

11 Hilman, Y.A. (2017). Kelembagaan Kebijakan Pariwisata di Level Desa, JIP (Jurnal Ilmu Pemerintahan): Kajian Ilmu Pemerintahan dan Politik Daerah, 2(2), 150-163, DOI: https://doi.org/10.24905/jip.2.2.2017.150-163, pp. 154-155, 157-158.

12 Mahadewi, K.J. (2019). Analisa Yuridis Keberlakuan Peraturan Daerah Provinsi Bali No 16 Tahun 2009 tentang Rencana Tata Ruang Wilayah Provinsi Bali Tahun 2009-2029 dalam Kerangka Filsafat Hukum, Progresif: Jurnal Hukum, 13(2), 167-182, DOI: https://doi.org/10.33019/progresif.v13i2.1454, pp. 169, 176-177. 
and planned processes that seek to meet current generation needs and can pass for future generations. It requires an effective and transparent, detailed and integrated policy instrument, as an implementation of the principles of good governance that involves active participation from the government, private sector, and society in tourism management. ${ }^{3}$ This paper will specifically complement the substance of the tourism development master plan that already exists in the Province and several districts. It will later become an example for several regencies and cities in Bali Province that do not have similar policies.

Putri Sanjiwani and Luh Putu Kerti Pujani stated that the regional government policy in developing agrotourism with the subject is Ban Village, Karangasem Regency also touches on the foundation of the Tourism Law that accommodates natural tourist attractions, cultural tourism attractions, and artificial tourism attractions. The decentralization of the division of government affairs also the decentralization of the tourism autonomy sector based on delegation authority based on the Regional Tourism Development Master Plan. This plan must not conflict with the Karangasem Regency Spatial and Regional Planning so that protected areas, conservation areas, vulnerable areas, or areas disaster-prone areas are not designated as areas or tourist attractions unless developing environmentally friendly and sustainable tourism such as agrotourism or ecotourism. ${ }^{14}$ This paper further complements the juridical aspects that emphasize the mandatory delegation authority for local governments to compile a tourism development master plan as a basis for tourism development.

Based on the important role of the tourism development master plan, there is the urgency to conduct an assessment related with a basis of authority related to policy in the form of a tourism development master plan; and realization of tourism target's, the scope and direction of the regulation, and the scope of the material for the content of the tourism development master plan, which in this case is intended to answer related problems.

\section{Research Method}

The paper is using a statute approach and focused on studying the conditions of legal norms. This study also uses a philosophical approach, a theoretical approach ${ }^{15}$ to examine and understand the direction of regulatory arrangements by regional governments relating to regulatory policies related to the tourism development master plan. The conceptual approach is carried out by examining views on the delegation of the tourism development master plan.

13 Suardana, I W. (2013). Analisis Kebijakan Pengembangan Pariwisata (Intervensi melalui Kebijakan Pariwisata Berkelanjutan di Bali), Paper was presented on Sustainable Tourism National Seminar held by Doctoral Program of Tourism, Udayana University, 2 May, 1-25, pp. 15-18.

14 Sanjiwani, P.K. \& Pujani, L.P.K. (2020). Kebijakan-Kebijakan Pemerintah Daerah dalam Pengembangan Pariwisata Kawasan Rawan Bencana di Desa Ban, Kabupaten Karangasem, Bali, Jurnal Ilmiah Pariwisata, 25(2), 133-140, DOI: https://doi.org/10.30647/jip.v25i2.1348, p. 137.

15 Muhdlor, A.Z. (2012). Perkembangan Metodologi Penelitian Hukum. Jurnal Hukum dan Peradilan, 1(2), 189-206, DOI: http:/ / dx.doi.org/10.25216/JHP.1.2.2012.189-206, pp. 194-195. 
This paper using primary legal materials are statutory regulations both in national and regional level inter alia Law concerning National Tourism, Bali Provincial Regulations concerning Culture Tourism and Bali Provincial Tourism Development Plan, Denpasar City, Badung Regency, and Tabanan Regency Regulation concerning Regional Tourism Development Plan. The secondary legal materials that used in this paper are legal textbooks, legal journals, and authorized publications from national and regional governments concerning tourism, specifically related with tourism development both in national and regional level.

The analysis techniques of legal materials used in this study are description, interpretation, systematization, argumentation, and evaluation techniques. ${ }^{16}$ At this stage of description, the presentation and determination of the meaning of the legal rules which are studied so that at this stage only describe what it is about a situation. ${ }^{17}$

This article also using legal hermeneutics. Legal hermeneutics is essentially a method of interpretation of legal texts or a method of understanding deeply about a normative text. The rule of law has two aspects, namely what is written in the form of sound legal texts, and what is implied is the idea behind the rule of law. ${ }^{18}$ Hermeneutics interpretation is an interpretation of the rule of law that is always related to its contents. Legal hermeneutics is essentially a method of interpretation of legal texts or a method of understanding a normative text.

\section{Results and Discussion}

\subsection{Formation of Laws and Regulations Principle}

Formation of laws and regulations is one of the activities of establishing law. According to the nature of the formation of law, it can be divided into two namely the establishment of written law in the form of treaties, judges' decisions, and statutory regulations and the establishment of unwritten laws in the form of adat law. According to Burkhardt Krems as revealed by $\mathrm{M}$. Fadli mentioned that the formation of legislation principle concerning: ${ }^{19}$

1. fill in the regulations (inhalt der regelung);

2. the form and arrangement of the rules (form der regelung);

3. the method of forming regulations (method der ausarbeitung der regelun); and

4. procedures and processes for establishing regulations (verfahren der ausarbeitung der regelung).

16 Sonata, D.L. (2014). Metode Penelitian Hukum Normatif dan Empiris: Karakteristik dari Metode Meneliti Hukum. Fiat Justisia Jurnal Ilmu Hukum, 8(1), 15-35, DOI: https://doi.org/10.25041/ fiatjustisia.v8no1.283, p. 27.

17 Wibisana, A.G. (2019). Menulis di Jurnal Hukum: Gagasan, Struktur, dan Gaya, Jurnal Hukum E Pembangunan 49(2), 471-496, DOI: http:/ /dx.doi.org/10.21143/jhp.vol49.no2.2014, p. 481.

18 Astariyani, N.L.G. \& Hermanto, B. (2019). Paradigma Keilmuan dalam Menyoal Eksistensi Peraturan Kebijakan dan Peraturan Perundang-undangan: Tafsir Putusan Mahkamah Agung, Jurnal Legislasi Indonesia 16(4), 433-447, pp. 439-440.

19 Fadli, M. (2018). Pembentukan Undang-undang yang Mengikuti Perkembangan Masyarakat. Jurnal Legislasi Indonesia, 15(1), 49-58, p. 53. 
In relation with authority to form laws and regulations, the formation legislation principle has very important to be considered to understand the scope and purpose of the formation of regulations, the principles of law as known realized as concrete form into the rule of law principle. ${ }^{20}$ Based on this understanding, the principles of law are not regulations (een rechtsbeginselen is niet een rechtregel) but no one regulations can be understood without knowing formation legislation legal principles (het recht is niet te begrijpen zonder die beginselen). Understanding the law not only looks at the rules but also must understand the underlying legislation formation principles. The principles of law must appear as the direction of law formation and enforcement of the law. ${ }^{21}$

In connection with the formation of the Regional Government Authority in establishing policies on the Tourism Development Master Plan, it was related to attribution and delegation of law and regulation formation that containing elements of:

1. Creation of (new) authority to make laws and regulations;

2. The authority is granted by the legislators or legislators to an institution; and

3. Institutions that accept authority are responsible for the exercise of that authority.

Attribution and delegation have both similarities and differences. The equation is the institution that accepts the authority responsible for the exercise of that authority. The difference related to delegation is always preceded by an attribution, while in the attribution there is no precedence on the other hand in attribution, the formation of authority occurs while in delegation there is the surrender of authority. ${ }^{22}$ In this context, the legislation formation principle being the guidance of delegation in the formation of legislation contains the following elements that delegation of authority to make laws and regulations; the authority is delegated by the holder of attributive authority (delegans) to other institutions (delegates); and the institutions that receive authority (delegataris) are responsible for the implementation of that authority.

\subsection{Public Policy Formulation Concept}

The formulation of public policy is a complicated process. Several methods for studying it have been developed by scientists who are interested in public policy. A popular method of dividing public policy formulation into stages and then analyzing each of these stages. First learn how problems arise and enter the government's agenda, how people formulate these problems to take action, what attitudes are taken by legislative organs or other institutions, how leaders implement policies, and finally, how policies it is evaluated.23 Problem formulation can be seen as a process with four interdependent

20 Esfandiari, F. (2018). Problematika Pendelegasian Peraturan Presiden dalam Hierarki Peraturan Perundang-undangan di Indonesia. Legality, 26(2), 267-280, DOI: https://doi.org/10.22219/jihl.v26i2.7800, p. 273.

21 Sukardi, S. \& Widiati, E.P. (2010). Pendelegasian Pengaturan oleh Undang-undang kepada Peraturan yang Lebih Rendah dan Akibat Hukumnya. Yuridika, 25(2), 103-116, DOI: 10.20473/ydk.v25i2.249, pp. 109-110.

22 Doludjawa, L. (2004). Catatan Kecil mengenai Ketentuan 'Delegasi' di dalam Lampiran UU Pembentukan Peraturan Perundang-undangan. Jurnal Legislasi Indonesia, 1(2), 39-44, pp. 4142.

23 Winarno, B. (2002). Teori dan Proses Kebijakan Publik, Yogyakarta: Med Press, pp. 55-56. 
phases, namely: recognition of problems, searching the problem, defining the problem, and specify the problem. ${ }^{24}$

Then explained that the precondition for problem formulation is recognition or "perceived existence" of the situation problem. To avoid a problem, an analyst is involved in problem-solving. At this stage, the short term goal is not the discovery of a single problem (for example, the problem of the client or analyst); but rather the discovery of several problem representations from various policy actors. Trained analysts usually face a large chaotic network of formulations of competing problems that are dynamic, shaped by social situations, and distributed throughout the policymaking process. ${ }^{25}$

In moving from a meta-problem to a substantive problem, the analysis seeks a problem define in the most basic and general terms. For example, an analyst can determine whether the problem is an economic, social, or political science problem. If the substantive problem is conceptualized as an economic problem, the analyst will treat it in terms of factors relating to the production and distribution of goods and services - for example, market prices determine the costs and benefits of public programs. Conversely, if the substantive problem is seen as a political or sociological problem, the analyst will approach it as a distribution of power and influence among competing interest groups, elites, and other societies. ${ }^{26}$

In the first stage, people see or feel a situation or event. Through observation can be understood as the background of the incident in the form of problems or problematic circumstances. In the second stage, the background of the situation or problem can be included in different science groups or aspects, so that it can be seen as an economic problem, political problem, legal problem, and any other problem, when the problem formulation is found, so those possible solutions can be sought (policy alternatives).

\subsection{Tourism Development Master Plan Concept}

The definition of tourism is based on Law Number 10 the Year 2009 concerning Tourism as the tourism activity varieties supported by various facilities and services that are provided by the part of a community, business people, the Government, and the Regional Government. Tourism is stated as a whole of tourism-related activities and describes as multidimensional and multidisciplinary areas subjects. Tourism also describes as the manifestation of each person's needs and entirely of a country as well as interactions all of the main components of tourism actors. ${ }^{27}$

24 Kurniawan, L.J. \& Lutfi, M. (2017). Hukum dan Kebijakan Publik: Perihal Negara, Masyarakat Sipil, dan Kearifan Lokal dalam Perspektif Politik Kesejahteraan, Malang: Setara Press, pp. 36-37.

25 Dunn, W.M. (2000). Pengantar Analisis Kebijakan Publik, terjemahan Edisi Kedua, Yogyakarta: Gadjah Mada University Press, pp. 18-19.

26 Akib, H. (2010) Implementasi Kebijakan: Apa, Mengapa dan Bagaimana, Jurnal Ilmiah Ilmu Administrasi Publik: Jurnal Pemikiran dan Penelitian Administrasi Publik 1(1), 1-11, DOI: https://doi.org/10.26858/jiap.v1i1.289, pp. 7-9.

27 Mudana, I.W. (2017). Pola Pemberdayaan Masyarakat pada Daerah Tujuan Wisata Bahari di Kabupaten Karangasem, Soshum: Jurnal Sosial dan Humaniora 7(3), 307-323, DOI: http://dx.doi.org/10.31940/soshum.v7i3.716, p. 317. 
Regional Tourism Destinations are geographical areas within one or more administrative regions with interrelation and interconnection between tourist attractions, public facilities, tourism facilities, accessibility, and communities. Travel Attractions (DTW) are all things that have uniqueness, beauty, values in the form of the diversity-related with natural wealth, culture, and handmade products as a destination of tourist visits target. ${ }^{28}$ In this context, Bali Tourism Destinations is a united tourism destination consisting of several tourism areas, special tourist attraction areas, and other areas that have tourist attractions following the Bali Provincial Spatial Plan.29

According to the Bali Provincial Regulation Number 10 Year 2015 concerning the Bali Province Regional Tourism Development Master Plan Period 2015-2029, Regional Tourism Development includes regional tourism destinations development; development of regional tourism marketing; development of regional tourism industry; and regional tourism institutions development. It was determined as the realization of quality and sustainable cultural tourism with competitiveness based on Tri Hita Karana that can encourage regional development and people's welfare. The regional tourism development realizing safe, comfortable, attractive tourism destinations by prioritizing the richness and diversity of environmentally friendly tourist attractions based on Balinese culture ensoul with Hinduism based on Tri Hita Karana; creating tourism marketing that is synergistic, quality, superior, responsible for increasing domestic and foreign tourist arrivals; realizing a competitive, credible tourism industry, opening space for broad public participation, being environmentally and social cultural responsible; and realizing the organization of provincial government, private and community, human resources, regulations, and effective efficient mechanisms for encouraging the realization of sustainable tourism.

The tourism development plan also includes improving the quality and quantity of tourism destinations and the tourism attractions diversity based on the local potential; conducting market activities by using various media in effective, efficient, and responsible ways; realizing the tourism industry that can drive the regional economy; and develop tourism institutions and tourism governance that can synergize the development of destinations, marketing, and tourism industry. ${ }^{30}$ The tourism

28 There are eight factor in the context tourism destinations development are (1) adequate and acceptable tourism product prices factor, (2) culture with it attractiveness factor, (3) beach with it attractive options factor, (4) convenience during staying and doing tourism activities factor, (5) chance for relaxation factor, (6) image that hold by Bali Island, (7) natural beauty attractiveness factor, and (8) hospitality of Balinese peoples factor. See further: Suradnya, I.M. (2006) Analisis Faktor-faktor Daya Tarik Wisata Bali dan Implikasinya terhadap Perencanaan Pariwisata Daerah Bali, SOCA: Jurnal Sosial Ekonomi Pertanian 6(3), 1-13, p. 6.

29 Muhaimin, M. (2018). Kedudukan Kearifan Lokal dalam Penataan Ruang Provinsi Bali. Jurnal Penelitian Hukum De Jure 18(1), 59-71, DOI: http://dx.doi.org/10.30641/dejure.2018.V18.5971, pp. 66-67.

30 In this context, Basuki Antariksa revealed that in national context, the needs for Central and Regional Government to regulating the Tourism Development Plan are first, the regulation would be instrument for expanded their economy with integrated policy pattern. Second, the chance of lifting unemployment, increasing their people welfare in this tourism destination, increasing the value/image of one geographical area, and brief revitalization of their economic resources within strengthen tourism destination. Third, for developing countries like Indonesia, it also holds their economic development without long-term investment and could reaching the higher level of national income. Fourth, there are also needs to integration of all 
development plan also including an increase of several number domestic and foreign tourist arrivals; increased length of stay; an increase in tourist spending; and increasing participation in tourism through the development of tourist villages.

Regional Tourism Development Direction includes the development of quality, community based, and sustainability of regional tourism; regional tourism development that is integrated across sectors, regions, and actors; regional tourism development that prioritizes the potential excellence of tourism areas, KDTWK, and DTW with development priorities that are following the theme of regional development; the development of DTW based on the potential of cultural, natural, and artificial appeal with local wisdom, and the regional tourism orientation towards equitable economic growth, increasing employment opportunities, reducing poverty, and preserving culture and the environment. The direction of regional tourism development is placed as the basis of policy direction, strategy, and program indication for each component of tourism development. ${ }^{31}$

Regional Tourism Destinations Development covers regional tourism destinations; construction of DTW; tourism accessible development; construction of public infrastructure, public and tourism facilities; empowerment of the community, and investment. Regional tourism destination territory covers tourism area; KDTWK, and DTW, that following the Provincial Spatial Plan. Development of tourism areas, KDTWK and DTW related with stages with priority criteria: has a destination component that is ready to be developed; has an effective position and role as a strategic investment attractor; has a strategic position as a systemic driving node for the development of tourism in the area, whether local, regional or national; has the potential for future tourism products; has a real contribution and/or a positive prospect in attracting the visit of foreign tourists and domestic tourists; and has regional, national and international competitive advantages. ${ }^{32}$

Tourism Area is a tourism strategic area within the geographical or rural administrative area within, which potentially for tourist attraction, with accessible and available of tourism facilities also social and cultural activities led by the community for tourism realized..$^{33}$ The tourism area including several criteria: the geographical area that covers one or more village or administrative units; has the potential of a tourist attraction; has

component of national or regional tourism within Tourism Development Plan and brought the efficiency and effectiveness of national capital flow management for tourism development. See further: Antariksa, B. (2016). Kebijakan Pembangunan Kepariwisataan: Pengembangan Kepariwisataan yang Berkelanjutan dan Perlindungan Kekayaan Intelektual, First Edition, Setara Press, Malang, pp. 35-36.

31 One of successful tourist destinations in Bali is Jatiluwih Village in Tabanan Regency. Jatiluwih well-known as agro-tourism village and being more prosperous under the Bali tourism development with Tri Hita Karana principle in their subak and near area in this agrotourism. Krismawintari, D. \& Utama, I.G.B.R. (2019). Kajian tentang Penerapan Community Based Tourism di Daya Tarik Wisata Jatiluwih, Tabanan, Bali. Jurnal Kajian Bali (Journal of Bali Studies) 9(2), 429-448, pp. 436-437.

32 Malik, F. (2016). Peranan Kebudayaan dalam Pencitraan Pariwisata Bali. Jurnal Kepariwisataan Indonesia: Jurnal Penelitian dan Pengembangan Kepariwisataan Indonesia 11(1), 67-92, p. 74.

33 Landra, P.T.C. (2018). Hukum Investasi dalam Industrialisasi Kepariwisataan Bali, Jurnal Magister Hukum Udayana 7(1), 100-121, DOI: https://doi.org/10.24843/ IMHU.2018.v07.i01.p09, pp. 111-113. 
adequate accessibility potential; has the availability of public or tourism facilities, and has integrated social-cultural activities related with tourism. Tourism Strategic Area is defined as an area which led the main function of tourism or potentially for tourism development with one or more important influence aspects. Special Tourism Attraction Area (KDTWK) define as a tourism strategic area located within geographical or rural administrative areas within potential values for tourism that supporting each other to realize the tourism, but its development has very limited direction for culture and environmental preservation. KDTWK shall be determined by the following criteria: geographical coverage within one or more rural administrative unit units; has the potential of a tourist attraction; has adequate accessibility potential; have the availability of public or tourism facilities; have integrated social-cultural activities related to tourism, and its development is very limited as the direction of cultural and environmental preservation.

The development of Balinese Culture Tourism is carried out with underlying the Bali Provincial Spatial Plan (RTRW). The development of tourism facilities and infrastructure outside the tourism area which has been determined in the Bali Provincial Spatial Plan (RTRW) is intended for Pakraman villages and traditional institutions. ${ }^{34}$ The development of tourism facilities and infrastructure using foreign capital facilities can only be carried out in the tourism area which has been stipulated in the Bali Provincial Spatial Plan (RTRW), and also carried out with due regard to diversity, unique culture, and nature of Bali under the necessity for travelling. ${ }^{35}$ In this context, Bali Cultural Tourism Development includes tourism businesses; tourism destination; tourism marketing; and also tourism institutions. The Government together with institutions related to tourism development shall carry out tourism research and development for supporting the tourism in Bali.

Tourism Destination Development includes feasibility study; planning; and infrastructure network within the cooperation of the Government with the Regency or City. The tourism destinations development must be carried out by taking into account inter alia local wisdom such as Balinese beliefs based on Tri Hita Karana and ensoul with Hinduism; preservation of culture and environment, like tradition, Balinese custom, and rules concerning the environment; economic potential for the community to provide an opportunity for local business both in the field of crafts and agricultural to exhibit their works in the field of tourist attraction; and the sustainable of tourism business. Bali Cultural components which are potentially for tourist attractions including art; archaeology; historic; museum; literature; tradition; and saujana. ${ }^{36}$

34 Wibawa, I.P.S. (2018). Hukum Tidak Tunggal: Potret Pluralisme Hukum dalam Pengaturan Kawasan Tempat Suci Pura Uluwatu di Bali, Dharmasmrti: Jurnal Ilmu Agama dan Kebudayaan 18(1), 45-53, DOI: https://doi.org/10.32795/dxs.v1i18.101, p. 46.

35 Jayantiari, I.G.A.M.R. (2017). Eksistensi Tanah Adat di Bali dan Problematika Hukum dalam Pengembangan Investasi, Kertha Patrika 39(2), DOI: https://doi.org/10.24843/KP.2017.v39.i02.p03, pp. 115-116.

36 Sanjiwani, P.K. (2015). Kewenangan Pemerintah Provinsi Bali dalam Pembangunan Pelabuhan Pariwisata sebagai Pendukung Pariwisata Bali, Jurnal Magister Hukum Udayana 4(4), DOI: https://doi.org/10.24843/JMHU.2015.v04.i04.p02, p. 641. 


\subsection{Legal Basis for Establishing a Local Government Authority Policy in Establishing a Policy Regarding the Tourism Development Master Plan}

The legislation and regulation that forms the legal basis for the formation Local Tourism Development Master Plan are stipulated and regulated in Article 18 paragraph (6) of the Indonesia's Constitution; Law Number 10 the Year 2009 regarding Tourism (as before also abbreviated as Law of Tourism); Law Number 23 the Year 2014 regarding Regional Government as amended for several times with the last version on Law Number 9 the Year 2015 (abbreviated as Regional Government Law); Government Regulation Number 50 of 2011 regarding the National Tourism Development Master Plan for 2010-2025; Regulation of the Minister of Tourism Number 10 the Year 2016 concerning Guidelines for Preparation of Provincial and Regency or City Tourism Development Master Plans; Bali Province Regional Regulation Number 2 the Year 2012 regarding Cultural Tourism of Bali; and Bali Province Regional Regulation Number 10 the Year 2015 regarding Bali Regional Tourism Development Master Plan of 2015-2029.

Government Administration in the form of a tourism development master plan is defined as a series of activities in the context necessary meeting services following statutory law for every citizen as the affected by the policy or plan. Bearing in mind the importance of the Indonesian government paying considerable attention to the tourism development master plan. This is proven by the need for several laws and regulations governing the master plan implementation to developing tourism.

The operation of tourism is classified as a governmental matter of choice under the authority of the region (Article 12 of Regional Government Law). Furthermore, Article 15 paragraph (1) of Regional Government Law determines the division of concurrent governmental affairs both of Central and Province and District or City-regions listed by the Appendix of Regional Government Law which is an inseparable part of this Law, especially in number I regarding Matrix of Division of Concurrent Government Affairs, Elucidation Part Z. Division of Affairs Tourism. ${ }^{37}$

In the Tourism Destination Sub Affairs, the Central Government has the authority in determining tourist attractions, tourism strategic areas, and tourism destinations; management of national tourism attractions; management of the national tourism strategic area; management of national tourism destinations; and stipulation of crossprovincial tourism business registration certificates. Provincial Government has the authority to manage provincial tourist attractions; management of the provincial tourism strategic area; management of provincial tourism destinations; stipulation of cross regency/city tourism business registration certificate in 1 (one) Provincial Region. Meanwhile, the Regency/City-Region Government has the authority to manage regency/city tourism attractions; management of the district/city tourism strategic area; management of regency/city tourism destinations; and stipulation of regency/city tourism business registration marks.

37 Said, A.R.A. (2015). Pembagian Kewenangan Pemerintah Pusat-Pemerintah Daerah dalam Otonomi Seluas-luasnya menurut UUD 1945, Fiat Justisia: Jurnal Ilmu Hukum 9(4), 577-604, DOI: https://doi.org/10.25041/fiatjustisia.v9no4.613, pp. 582, 588, 591-592. See also, for the substance of Elucidation in the Act or Law: Hermanto, B., Aryani, N.M. \& Astariyani, N.L.G. (2020). 
In the Tourism Destination Sub Affairs, the Central Government has the authority in marketing domestic and foreign tourism attractions, destinations, and strategic areas of national tourism. The Provincial Government is authorized in the marketing of domestic and foreign tourism attractions, destinations and the provincial strategic tourism area Whereas the Regency/City Government has the authority in marketing domestic and foreign tourism attractions, destinations, and strategic districts/cities.

In the Creative Economy Development through the Intellectual Property Rights Utilization and Protection Sub Affairs, the Central Government has the authority to develop a national creative economy determined by criteria. Province Government has the authority for providing the facilities and infrastructure for creative cities, while Regency/City Governments have the authority to provide infrastructure (creative zones/creative spaces/creative cities) as a space for expression, promotion, and interaction for creative people in regency/city regions.

In the Tourism Resources Development and Creative Economy Sub Affairs, the authorities of Central Government in the Development of Tourism Resources and Creative Economy, the Province Government shall to implementing development of capacity of human resources for tourism and the creative economy at an advanced level, and the Regency/City Government has the authority to carry out increased human resource capacity for tourism and a basic level of the creative economy. Based on the Local Government Law, the Tourism Law, and the Government Regulation on Ripparnas, it can be interpreted as the basis for the authority of the form of delegation arrangements relating to the Tourism Development Master Plan.

The theoretical view concerning the validity of regulations called as the validity of legislation in the normative domain and sociological. Understanding in the sociological realm appears in those contained in parentheses. ${ }^{38}$ In the context of the basis of the validity of legislation relating to the formation of legislation, it is more appropriate to understand the basis of the validity of legislation in the normative domain. ${ }^{39}$ The basis of political legitimacy in the normative domain is describing legal politics, namely the existence of basic ideals and norms reflected in the 1945 Indonesia Constitution, which can be accommodated in philosophical and juridical grounds, as well as the basis of political validity that illustrates the political lines of law in the People's Consultative Assembly Decree's (Tap MPR), which can be accommodated on a juridical basis. ${ }^{40}$

The basis of validity or the basis of the validity of regulations, the philosophy, sociology, and juridical basis that includes philosophical foundations that reflect philosophical values or values contained in the ideals of law and are needed as a means of ensuring justice, the foundation sociological activities that reflect the demands or needs of the community that requires resolution are needed as a means of guaranteeing benefits, as

38 Penegasan Kedudukan Penjelasan Suatu Undang-undang: Tafsir Putusan Mahkamah Konstitusi, Jurnal Legislasi Indonesia 17(3), 251-268, pp. 259-260

39 Nazriyah, R. (2002). Peranan Cita Hukum dalam Pembentukan Hukum Nasional, Ius Quia Iustum: Jurnal Ilmu Hukum 9(20), 136-151, DOI: https://doi.org/10.20885/ iustum.vol9.iss20.art11, p. 137.

40 Fajarwati, M. (2018). Konstitusionalitas Ketetapan Majelis Permusyawaratan Rakyat dalam Hierarki Peraturan Perundang-undangan, Jurnal Hukum \& Pembangunan 48(1), 70-89, DOI: http://dx.doi.org/10.21143/vol48.no1.1596 , pp. 79-82. 
well as a legal basis that reflects the need for consistency of legal provisions, both concerning the basis of authority and procedures for formation, as well as the type and material content, as well as the absence of contradictions between equal legal provisions and with higher and needed as a means of ensuring legal certainty.

The responsibility of the State is mandated in the Fourth Alinea of the Preamble of the 1945 Constitution of the Republic Indonesia (Indonesian Constitution) inter alia protecting all Indonesia's citizens and spilling Indonesia's blood and also promoting the public welfare. ${ }^{41}$ In the Authority of Regional Governments in Establishing Policies on the Master Plan for Tourism Development as for the elaboration of the foundation of legitimacy as in the form of philosophical foundations for realizing a just and prosperous society in the form of regulations relating to the Authority of Regional Governments in Setting Policies on the Master Plan for Tourism Development, a sociological foundation to realize welfare the public is seen as needing arrangements related to the Authority of Regional Governments in Establishing Policies on Tourism Development Master Plans, as well as the juridical basis concerning providing the legal basis and certainty for the formulation of policies of Tourism Development Master Plan.

The basic of the delegation continues based on the content of the regulations to be formed, it should be noted what constitutes the material to be formed. The term material content was introduced by A.Hamid S.Attamimi as a substitution for the Dutch term Het ondrwerp in the Thorbecke expression "het eigenaardig onderwerp der wet" which was translated with material content typical of the law, A.Hamid.S.Attimiimi introduced material content terms. The word material content was introduced by the author as a substitute for the Dutch word het onderwerp in the expression Thorbecke het eigenaardig onderwerp der wet. 42 This can be translated into material that is unique to the law, that is, specific regulatory material that is only and solely contained in the law so that it becomes the subject matter of the law. Every law and regulation has its content in stages and varies. 43

Sri Soemantri as mentioned by Retno Saraswati also believes that the same laws and regulations do not regulate the same material content, what is regulated by law will be different from what is regulated by local regulations. ${ }^{44}$ Likewise, what is regulated in the Indonesian Constitution is also different from what is stipulated in a presidential regulation. Rosjidi Ranggawidjaja stated what was meant by the contents of the content

41 Aryani, N.M. \& Hermanto, B. (2018). Gagasan Pengaturan yang Ideal Penyelesaian Yudisial maupun Ekstrayudisial Pelanggaran Hak Asasi Manusia di Indonesia. Jurnal Legislasi Indonesia 15(4), 369-383, pp. 374-375.

42 Anggono, B.D. (2018). Tertib Jenis, Hierarki, dan Materi Muatan Peraturan Perundangundangan: Permasalahan dan Solusinya, Masalah-masalah Hukum, 47(1), 1-9, DOI: 10.14710/mmh.47.1.2018.1-9, p. 6.

43 Barlian, A.E.A., (2016). Konsistensi Pembentukan Peraturan Daerah berdasarkan Hierarki Perundang-undangan dalam Prespektif Politik Hukum, Fiat Justisia: Jurnal Ilmu Hukum 10(4), 605-622, DOI: https://doi.org/10.25041/ fiatjustisia.v10no4 801, pp. 616-617.

44 Saraswati, R. (2013). Problematika Hukum Undang-undang No. 12 Tahun 2011 tentang Pembentukan Peraturan Perundang-undangan", Yustisia, 2(3), 97-103, DOI: https://doi.org/10.20961/yustisia.v2i3.10164, pp. 99-100. 
or substance contained in the particular law and the laws and regulations in general. ${ }^{45}$ The term material content is not only used in discussing the law but also all statutory regulations and remembering the formulation of the charge material is an important part of the formation of legislation.46 Concerning material content in the context of implementing Regional Regulations as regulates in Article 14 of the Law Number 12 the Year 2011 juncto Law Number 15 the Year 2019 concerning the Formation of Regulations, regulates that the content of Regional Regulations contains content material in the framework to carry out the regional autonomy and regulates the co-administration tasks or to accommodate special regional conditions and/or further elaboration of the higher Regulations. ${ }^{47}$

Delegation to the Authority appears in the character of regional regulations as laws and regulations that apply to and bind citizens also decrease in the character of regional regulations. The general binding force of the charge material is not the same as the binding material of the regional regulation but only applies to the charge material. ${ }^{48}$

The Authority of the Regional Government in Establishing a Policy regarding the Bali Tourism Master Plan appears in the model or pattern of material preparation in the preparation of regional regulations that have been prepared. The stipulation of the policy regarding the tourism development master plan in the Province has been determined by the Province and several City/Regencies Government with the Bali Provincial Regulation Number 10 the Year 2015, Badung Regional Regulation Number 17 the Year 2017, Jembrana Regional Regulation Number 1 the Year 2018 and Denpasar Regional Regulation Number 3 the Year 2019.

The arrangements are outlined in Regional Regulations covering development Regional Tourism Destinations; Tourism Marketing Development; Development of Regional Tourism Industry; and Tourism Institutional Development, which is reflected in the material content of Article 9 paragraph (3) of Tourism Law directed to a stipulation by the Regional Regulation on the Tourism Development Master Plan, it is well regulated in Bali Provincial Regulation Number 10 the Year 2015 concerning the 2015-2019 Tourism Master Plan reflected in Chapter II Regional Tourism Development, Chapter III Regional Tourism Destination Development, Chapter IV Regional Tourism Marketing Development, Chapter V Regional Tourism Industry Development. The Badung Regional Regulation Number 17 the Year 2017 also regulating the contents of the Law on Tourism namely in Chapter III Principles, Vision and Mission of Tourism Development, Chapter V Tourism Policy and Development Strategy, Chapter VI Tourism Area Development Plan, and Chapter VII Tourism Development Program. The

45 Putra, I.B.W. (2017). Perumusan Materi Muatan Peraturan Daerah, Makalah disampaikan Semiloka Penyusunan Produk Hukum Daerah diselenggarakan Unit Pusat Perancangan Hukum, Fakultas Hukum Universitas Udayana, 1-7, pp. 4-5.

46 Wijayanti, W. (2013). Eksistensi Undang-undang sebagai Produk Hukum dalam Pemenuhan Keadilan bagi Rakyat (Analisis Putusan Mahkamah Konstitusi Nomor 50/PUU-X/2012), Jurnal Konstitusi, 10(1), 197-204, DOI: https://doi.org/10.31078/jk\%25x, pp. 200.

47 Saraswati, R. (2009). Perkembangan Pengaturan Sumber Hukum dan Tata Urutan Peraturan Perundang-undangan di Indonesia. Media Hukum, IX(2), 1-12, pp. 7-8.

48 Kasmawati, A. (2010). Implikasi Hukum Kebijakan Desentralisasi dalam Hubungan Kewenangan antartingkat Pemerintahan Negara Kesatuan, Ius Quia Iustum: Jurnal Hukum, 17(4), 552-566, DOI: https://doi.org/10.20885/iustum.vol17.iss4.art3, p. 558. 
Jembrana Regional Regulation Number 1 the Year 2018 also regulates the content of the Tourism Act reflected in Chapter II Regional Tourism Development, Chapter III Regional Tourism Destination Development, Chapter IV Regional Tourism Marketing Development, Chapter V Regional Tourism Industry Development, Chapter VI Institutional Development of Regional Tourism, and Chapter VII Indications of the Regional Tourism Development Program. Finally, the Denpasar Regional Regulation Number 3 the Year 2019 also regulates the content of the Tourism Act reflected in Chapter V Regional Tourism Development, Regional Tourism Marketing Development (in separate articles) and Regional Tourism Industry Development (in separate articles), and also Chapter VI Regional Tourism Destination Development.

However, the other regencies in Bali Province still have not any specific regional regulation concerning Tourism Development Plan and based on the substance of the Bali Provincial Regulation Number 10 the Year 2015, it should be regulates in the form of regency regional regulation by the other regencies, outside from Badung Regency, Jembrana Regency and Denpasar City. This matter is related to the commitment and needs to regulate inclusive tourism development to strengthen regional development. It also has a positive impact on national welfare and regional welfare standard within an effective, efficient, and integrated policy of the regional Tourism Development Plan.

\section{Conclusion}

First, the problems faced are related to the Tourism Development Master Plan. The basis of the authority for the delegation of formation arrangements is regulated in the Tourism Act, the Regional Government Act, and the Government Regulation related to Master Plan of National Tourism Development. This problem was overcome by making a Regional Regulation concerning Tourism Master Plan. This description in the material content is about first, General Provisions; second, Position, Scope and Period of Implementation; third, Principles, Vision and Mission of Tourism Development; fourth, Objectives and Objectives; fifth, Tourism Development Policy and Strategy; sixth, Tourism Region Development Plan; seventh, Tourism development program; and eighth, Supervision and Control.

Second, the direction, target, and scope of the regulation, and the scope of the content of the Regional Regulation related with the authority of the Regional Government in setting policies regarding the master plan to be formed the direction of regulation of the Regional Regulation to be formed is to provide a basis and legal certainty for the Tourism Development Master Plan; the target to be realized from the Regional Regulation that will be formed is to realize Tourism Development Master Plan; and scope of the regulation of the Regional Regulation that will be formed is to provide guidelines relating to the master plan. Basis of local government authority in setting policies as stipulated in the Indonesia Constitution and the statutory law in national level also the regional and local level, within Bali Province Government with the enactment of Bali Provincial Regulation Number 10 the Year 2015; Badung Regional Regulation Number 17 the Year 2017; Jembrana Regional Regulation Number 1 the Year 2018 and Denpasar Regional Regulation Number 3 the Year 2019. In connection with the regional government authority in determining master plan, which is based on the Tourism Act, the authority of affairs national statutory law determines the obligations of the regional government in relation with delegation of authority. It is also necessary to establish the 
policy immediately followed up by other Regency and City Governments within the Bali Province Government .

\section{Bibliography}

\section{Books}

Antariksa, B. (2016). Kebijakan Pembangunan Kepariwisataan: Pengembangan Kepariwisataan yang Berkelanjutan dan Perlindungan Kekayaan Intelektual, First Edition, Setara Press, Malang.

Arranged Team of Statistic Centre of Bali Province Publications, 2020, Statistik Wisatawan Mancanegara ke Bali 2019 (Foreign Tourist Statistics of Bali Province 2019), First Edition, Badan Pusat Statistik Provinsi Bali, Denpasar.

Arranged Team of Statistic Centre of Bali Province Publications, 2020, Provinsi Bali dalam Angka 2020 (Bali Provinces in Figure 2020), First Edition, Badan Pusat Statistik Provinsi Bali, Denpasar.

Dunn, W.M. (2000). Pengantar Analisis Kebijakan Publik, terjemahan Edisi Kedua, Yogyakarta: Gadjah Mada University Press.

Kurniawan, L.J. \& Lutfi, M. (2017). Hukum dan Kebijakan Publik: Perihal Negara, Masyarakat Sipil, dan Kearifan Lokal dalam Perspektif Politik Kesejahteraan, Malang: Setara Press.

Winarno, B. (2002). Teori dan Proses Kebijakan Publik, Yogyakarta: Med Press.

\section{Publication and Related Journals}

Akib, H. (2010) Implementasi Kebijakan: Apa, Mengapa dan Bagaimana, Jurnal Ilmiah Ilmu Administrasi Publik: Jurnal Pemikiran dan Penelitian Administrasi Publik 1(1), 111, DOI: https://doi.org/10.26858/jiap.v1i1.289.

Anggono, B.D. (2018). Tertib Jenis, Hierarki, dan Materi Muatan Peraturan Perundangundangan: Permasalahan dan Solusinya, Masalah-masalah Hukum, 47(1), 1-9, DOI: 10.14710/mmh.47.1.2018.1-9.

Aryani, N.M. \& Hermanto, B. (2018). Gagasan Pengaturan yang Ideal Penyelesaian Yudisial maupun Ekstrayudisial Pelanggaran Hak Asasi Manusia di Indonesia. Jurnal Legislasi Indonesia 15(4), 369-383.

Astariyani, N.L.G. \& Nurmawati, M. (2017). Drafting the Substance Materials of the Regional Regulation of Badung Regency on Public Service. Udayana Journal of Social Science and Humanities 1 (1), 42-45, DOI: https//doi.org/10.24843/UJoSSH.2017.v01.i01.p08.

Astariyani, N.L.G., Sudiarta, I.K. \& Dewi, C.I.D.W.P. (2019). Legal Hermeneutics in the Preparation of a Case in the Province of Bali. Udayana Journal of Social Science and Humanities 3(1), 33-39, DOI: https/ / doi.org/10.24843/UJoSSH.2019.v03.i01.p06.

Astariyani, N.L.G. \& Hermanto, B. (2019). Paradigma Keilmuan dalam Menyoal Eksistensi Peraturan Kebijakan dan Peraturan Perundang-undangan: Tafsir Putusan Mahkamah Agung, Jurnal Legislasi Indonesia 16(4), 433-447.

Barlian, A.E.A., 2016,"Konsistensi Pembentukan Peraturan Daerah berdasarkan Hierarki Perundang-undangan dalam Prespektif Politik Hukum", Fiat Justisia: 
Jurnal Ilmu Hukum, Volume 10, Nomor 4, October-Desember, 605-622, DOI: https://doi.org/10.25041/fiatjustisia.v10no4.801.

Dharmawan, N.K.S., Sarjana, M. \& Samshitawrati, P.A. (2017). Perusahaan dan Konservasi Keanekaragaman Hayati Laut: The Right to Tourism vs Sustainable Tourism, Masalah-masalah Hukum, 46(2), 125-135. DOI: 10.14710/mmh.46.2.2017.125-135.

Doludjawa, L. (2004). Catatan Kecil mengenai Ketentuan 'Delegasi' di dalam Lampiran UU Pembentukan Peraturan Perundang-undangan. Jurnal Legislasi Indonesia, $1(2), 39-44$.

Esfandiari, F. (2018). Problematika Pendelegasian Peraturan Presiden dalam Hierarki Peraturan Perundang-undangan di Indonesia. Legality, 26(2), 267-280, DOI: https://doi.org/10.22219/jihl.v26i2.7800.

Fadli, M. (2018). Pembentukan Undang-undang yang Mengikuti Perkembangan Masyarakat. Jurnal Legislasi Indonesia, 15(1), 49-58.

Fajarwati, M. (2018). Konstitusionalitas Ketetapan Majelis Permusyawaratan Rakyat dalam Hierarki Peraturan Perundang-undangan, Jurnal Hukum \& Pembangunan 48(1), 70-89, DOI: http://dx.doi.org/10.21143/vol48.no1.1596.

Febriansyah, F.I. (2016). Konsep Pembentukan Peraturan Perundang-undangan di Indonesia. Perspektif: Kajian Masalah Hukum dan Pembangunan, XXI(3), 220-229, DOI: http:/ / dx.doi.org/10.30742/ perspektif.v21i3.586.

Hadat, H. (2020). Eksistensi Tri Hita Karana dalam Pembentukan Peraturan Hukum di Bali (Perspektif Filsafat Ilmu). Jurnal Magister Hukum Udayana 9(1), 132-141, DOI: https://doi.org/10.24843/JMHU.2020.v09.i01.p09.

Hermanto, B., Aryani, N.M. \& Astariyani, N.L.G. (2020). Penegasan Kedudukan Penjelasan Suatu Undang-undang: Tafsir Putusan Mahkamah Konstitusi, Jurnal Legislasi Indonesia 17(3), 251-268.

Hilman, Y.A. (2017). Kelembagaan Kebijakan Pariwisata di Level Desa, JIP (Jurnal Ilmu Pemerintahan): Kajian Ilmu Pemerintahan dan Politik Daerah, 2(2), 150-163, DOI: https://doi.org/10.24905/jip.2.2.2017.150-163.

Jayantiari, I.G.A.M.R. (2017). Eksistensi Tanah Adat di Bali dan Problematika Hukum dalam Pengembangan Investasi, Kertha Patrika 39(2), DOI: https:/ / doi.org/10.24843/KP.2017.v39.i02.p03.

Kasmawati, A. (2010). Implikasi Hukum Kebijakan Desentralisasi dalam Hubungan Kewenangan antartingkat Pemerintahan Negara Kesatuan, Ius Quia Iustum: Jurnal Hukum, 17(4), 552-566, DOI: https://doi.org/10.20885/iustum.vol17.iss4.art3.

Krismawintari, D. \& Utama, I.G.B.R. (2019). Kajian tentang Penerapan Community Based Tourism di Daya Tarik Wisata Jatiluwih, Tabanan, Bali. Jurnal Kajian Bali (Journal of Bali Studies) 9(2), 429-448.

Landra, P.T.C. (2018). Hukum Investasi dalam Industrialisasi Kepariwisataan Bali, Jurnal Magister Hukum Udayana 7(1), 100-121, DOI: https://doi.org/10.24843/JMHU.2018.v07.i01.p09. 
Mahadewi, K.J. (2019). Analisa Yuridis Keberlakuan Peraturan Daerah Provinsi Bali No 16 Tahun 2009 tentang Rencana Tata Ruang Wilayah Provinsi Bali Tahun 20092029 dalam Kerangka Filsafat Hukum, Progresif: Jurnal Hukum, 13(2), 167-182, DOI: https:/ / doi.org/10.33019/ progresif.v13i2.1454.

Malik, F. (2016). Peranan Kebudayaan dalam Pencitraan Pariwisata Bali. Jurnal Kepariwisataan Indonesia: Jurnal Penelitian dan Pengembangan Kepariwisataan Indonesia 11(1), 67-92.

Mudana, I.W. (2017). Pola Pemberdayaan Masyarakat pada Daerah Tujuan Wisata Bahari di Kabupaten Karangasem, Soshum: Jurnal Sosial dan Humaniora 7(3), 307323, DOI: http:/ /dx.doi.org/10.31940/soshum.v7i3.716.

Muhaimin, M. (2018). Kedudukan Kearifan Lokal dalam Penataan Ruang Provinsi Bali. Jurnal Penelitian Hukum De Jure 18(1), 59-71, DOI: http://dx.doi.org/10.30641/dejure.2018.V18.59-71.

Muhdlor, A.Z. (2012). Perkembangan Metodologi Penelitian Hukum. Jurnal Hukum dan Peradilan, 1(2), 189-206, DOI: http:/ / dx.doi.org/10.25216/JHP.1.2.2012.189-206.

Nazriyah, R. (2002). Peranan Cita Hukum dalam Pembentukan Hukum Nasional, Ius Quia Iustum: Jurnal Ilmu Hukum 9(20), 136-151, DOI: https://doi.org/10.20885/iustum.vol9.iss20.art11.

Putra, I.B.W. (2017). Perumusan Materi Muatan Peraturan Daerah, Makalah disampaikan Semiloka Penyusunan Produk Hukum Daerah diselenggarakan Unit Pusat Perancangan Hukum, Fakultas Hukum Universitas Udayana, 1-7.

Said, A.R.A. (2015). Pembagian Kewenangan Pemerintah Pusat-Pemerintah Daerah dalam Otonomi Seluas-luasnya menurut UUD 1945, Fiat Justisia: Jurnal Ilmu Hukum 9(4), 577-604, DOI: https:/ / doi.org/10.25041/ fiatjustisia.v9no4.613.

Salain, M.S.P.D. (2017). Perlindungan Hukum terhadap Kebudayaan Bali sebagai Sumber Daya Ekonomi Pariwisata. Kertha Patrika 39(1), 1-15, DOI: https:// doi.org/10.24843/KP.2017.v39.i01.p01.

Sandang, Y. (2019). Pengarusutamaan Prinsip-Prinsip Bisnis dan Hak Asasi Manusia Bagi Sektor Pariwisata di Indonesia. Jurnal HAM 10(1), 1-17, DOI: http://dx.doi.org/10.30641.ham.2019.10.1-17.

Sanjiwani, P.K. (2015). Kewenangan Pemerintah Provinsi Bali dalam Pembangunan Pelabuhan Pariwisata sebagai Pendukung Pariwisata Bali, Jurnal Magister Hukum Udayana 4(4), DOI: https:/ / doi.org/10.24843/JMHU.2015.v04.i04.p02.

Sanjiwani, P.K. \& Pujani, L.P.K. (2020). Kebijakan-Kebijakan Pemerintah Daerah dalam Pengembangan Pariwisata Kawasan Rawan Bencana di Desa Ban, Kabupaten Karangasem, Bali, Jurnal Ilmiah Pariwisata, 25(2), 133-140, DOI: https://doi.org/10.30647/jip.v25i2.1348.

Saraswati, R. (2009). Perkembangan Pengaturan Sumber Hukum dan Tata Urutan Peraturan Perundang-undangan di Indonesia. Media Hukum, IX(2), 1-12.

Saraswati, R. (2013). Problematika Hukum Undang-undang No. 12 Tahun 2011 tentang Pembentukan Peraturan Perundang-undangan", Yustisia, 2(3), 97-103, DOI: https://doi.org/10.20961/yustisia.v2i3.10164. 
Sonata, D.L. (2014). Metode Penelitian Hukum Normatif dan Empiris: Karakteristik dari Metode Meneliti Hukum. Fiat Justisia Jurnal Ilmu Hukum, 8(1), 15-35, DOI: https://doi.org/10.25041/fiatjustisia.v8no1.283.

Suardana, I W. (2013). Analisis Kebijakan Pengembangan Pariwisata (Intervensi melalui Kebijakan Pariwisata Berkelanjutan di Bali), Paper was presented on Sustainable Tourism National Seminar held by Doctoral Program of Tourism, Udayana University, 2 May, 1-25.

Suharjono, M. (2014). Pembentukan Peraturan Daerah yang Responsif dalam Mendukung Otonomi Daerah. DIH Jurnal Ilmu Hukum, 10(19), 21-37, DOI: https://doi.org/10.30996/dih.v10.i19.281.

Sukardi, S. \& Widiati, E.P. (2010). Pendelegasian Pengaturan oleh Undang-undang kepada Peraturan yang Lebih Rendah dan Akibat Hukumnya. Yuridika, 25(2), 103-116, DOI: 10.20473/ydk.v25i2.249.

Suradnya, I.M. (2006), Analisis Faktor-faktor Daya Tarik Wisata Bali dan Implikasinya terhadap Perencanaan Pariwisata Daerah Bali, SOCA: Jurnal Sosial Ekonomi Pertanian 6(3), 1-13.

Wibawa, I.P.S. (2018). Hukum Tidak Tunggal: Potret Pluralisme Hukum dalam Pengaturan Kawasan Tempat Suci Pura Uluwatu di Bali, Dharmasmrti: Jurnal Ilmu Agama dan Kebudayaan 18(1), 45-53, DOI: https://doi.org/10.32795/dxs.v1i18.101.

Wibisana, A.G. (2019). Menulis di Jurnal Hukum: Gagasan, Struktur, dan Gaya, Jurnal Hukum E Pembangunan 49(2), 471-496, DOI: http://dx.doi.org/10.21143/jhp.vol49.no2.2014.

Wijayanti, W. (2013). Eksistensi Undang-undang sebagai Produk Hukum dalam Pemenuhan Keadilan bagi Rakyat (Analisis Putusan Mahkamah Konstitusi Nomor 50/PUU-X/2012), Jurnal Konstitusi, 10(1), 197-204, DOI: https://doi.org/10.31078/jk\%25x.

\section{Statutory Law and Regulations}

The 1945 Constitution of the Republic of Indonesia

Law Number 10 the Year 2009 regarding Tourism.

Law Number 12 the Year 2011 jo. Law Number 15 the Year 2019 concerning the Formation of Regulations.

Law Number 23 the Year 2014 jo. Law Number 9 the Year 2015 regarding Regional Government.

Government Regulation Number 50 of 2011 regarding the National Tourism Development Master Plan for 2010-2025.

Bali Provincial Regional Regulation Number 2 the Year 2012 regarding Cultural Tourism of Bali.

Bali Provincial Regional Regulation Number 10 the Year 2015 regarding Tourism Master Plan for 2015-2019. 
Badung Regional Regulation Number 17 the Year 2017 regarding Tourism Development Master Plan for Badung Regency 2017 - 2025.

Jembrana Regional Regulation Number 1 the Year 2018 regarding Regional Tourism Development Master Plan for 2018-2032.

Denpasar Regional Regulation Number 3 the Year 2019 regarding Regional Tourism Development Master Plan for 2018-2029.

Regulation of the Minister of Tourism Number 10 the Year 2016 regarding Guidelines for Preparation of Provincial and Regency / City Tourism Development Master Plans. 